\title{
A BALATON RÉGIÓ FEJLETTSÉGÉT MEGHATÁROZÓ VÁLTOZÓKNAK ÉS A TELEPÜLÉSI SZAKEMBEREK VÉLEMÉNYÉNEK ÖSSZEHASONLÍTÓ ELEMZÉSE
}

\author{
(Comparing Analysis of the Determining Variables of Balaton- \\ Region Development and the Opinion of Settlement Specialists)
}

\section{MARTON ISTVÁN}

Kulcsszavak:

fejlettség-fejlesztés súlyozás preferencia sorrend

A tanulmányt megalapozó kutatás egy speciális adottságokkal rendelkezó turisztikai régióban (Balaton régió) folyt. A Balaton Közép-Európa legnagyobb, és egyben legsekélyebb édesvizi tava, amely körül a 19. század végétöl kezdve jelentös turisztikai aktivitás figyelhetö meg. A turizmus egyenlötlen elterjedése következtében a Balaton régióban a területi egyenlötlenségek sajátos módon alakultak ki. Mindamellett, hogy a fejlettségbeli különbségek általában a nagyobb és a kisebb lélekszámú települések között jelentkeznek, a Balaton régióban a területi egyenloótlenségek döntöen nem a településmérettel vannak összhangban. A régió településeinek fejlettségét sokkal inkább a Balaton-parthoz való közelség határozza meg.

\section{A kutatás elözményei, célja}

A fejlett és fejletlen területek jelenléte a gazdasági térben, a társadalom és gazdaság térbeli tagolódása mindinkább elótérbe került az elmúlt évtizedekben (Nemes Nagy 2005). A jelentös regionális változások világszerte, így természetszerúleg hazánkban is, területileg élesen megjelenỏ társadalmi és gazdasági különbségek átrétegződését, felerősödését hozták magukkal. A területi fejlódés egyenetlenségei folytán jelentoos különbségek alakultak ki nemcsak a régiók között, de a régiókon belül is. Bár az európai uniós csatlakozásunkkal ezeknek a területi különbségeknek a csökkentésére felhasználható fejlesztési forrásaink a többszörösére növekedtek, a Balaton régióban a források szủkösségéből adódóan nem lehet mindent egyszerre és azonos mértékben fejleszteni. Amennyiben a rendelkezésre álló eröforrásokat szétaprózva használjuk fel, csak kismértékủ javulás válna lehetôvé mindenütt, amivel csak a jelenlegi (áldatlan) állapotokat lehetne konzerválni. Mindezek okán ki kell választani egy olyan prioritási sorrendet, melyben a helyi szakemberek véleményét is figyelembe kell venni. A tanulmány elemzései azt mutatják, hogy a települési szakemberek (polgármesterek, jegyzők) fejlesztési prioritási sorrendje és a meg-lévő, statisztikailag mérhető adottságok színvonala számos esetben eltér egymástól. Mindezeket átgondolva, a regionális tervezésnél figyelmet kell szentelni azoknak a területeknek a fejlesztésére, amelyek a településeken dolgozó szakemberek véleménye 
szerint az átlagosnál nagyobb szerepet játszanak a település életében, de a statisztikailag mérhető teljesítményük elmarad a többi átlagától.

A Balaton térség vizsgálatakor szem elött kell tartani, hogy a régió sem a regionális, sem a megyehatárokhoz nem illeszkedik, de még statisztikai kistérségekkel sem fedhetö le. A 13 érintett kistérség közül csupán a balatonfüredi, balatonalmádi és a fonyódi helyezkedik el teljes területével a régión belül, az ajkai és a zalaszentgróti kistérségböl csupán egy-egy települést soroltak az uidülökörzethez, tehát az elemzéseket mindenképpen települési szintủ alapadatok felhasználásával készíthetjük. A terilleti, statisztikai adatokkal végzett elemzések azonban, bármilyen pontos alapadatokra támaszkodó mutatórendszerekkel dolgoznak is, nem képesek figyelembe venni a területi sajátosságokat, és ebböl kifolyólag elfedhetnek fontos eredményeket. Az eredmények pontosítása érdekében tehát a statisztikai módszerekkel előállított változók közé, a települési szakemberek véleményének figyelembevételével kialakított, az adott térségi jellemzök által meghatározott változók bevonása szükséges. A vizsgált települések sajátos adottságait legjobban ismerök így egy átgondolt és célirányos rendszerben segíthetik a területi vizsgálatokat.

\section{A kutatás módszertana}

A tanulmány elemzései a 2000. évi CXII. törvényben (Balaton törvény) lehatárolt településkörre vonatkoznak: a térséghez 164 település tartozik, melyek összefüggő területet alkotnak a Balaton körül Somogy, Veszprém és Zala megye határán. A törvényben meghatározottak szerint 52 partközeli és 112 további település található a Balaton régióban.

\section{Komplex Fejlettségi Mutató (KFM)}

A vizsgálathoz a Balaton régió településszintü adatai (KSH, T-STAR) álltak rendelkezésre 2002. év végére vonatkozólag. Az elemzésbe összesen 36 változó került be (1. táblázat). A vizsgált változók egyrészt a települések gazdasági fejlettségét jellemezték, és hasonlóak voltak a 24/2001. (IV. 20.) OGY. határozatban szereplö, a területfejlesztés kedvezményezett térségeinek lehatárolásához használt mutatókhoz. Másrészt a T-STAR adatbázisból lettek kiválasztva olyan változók, amelyek az adott település turisztikai forgalmát mutatták. Véleményünk szerint a Balaton régió speciális helyzetéböl adódóan a különbözö statisztikai mutatók nem egyforma fontosságúak a térségben, ezért azokat egy komplex mutató megalkotásánál különbözö súllyal kell figyelembe venni. A súlyértékek kialakításánál a régió településein dolgozó szakemberek véleményét tartottuk elsödlegesnek, mivel ök rendelkeznek a legpontosabb információkkal mindazon sajátosságról, amelyek meghatározhatják az egyes mutatók szerepét. A szakemberek véleményének felmérése során azt vizsgáltuk, hogy a Balaton régió településeinek irányító testülete (polgármesterek, jegyzök, körjegyzök, és ahol volt, a turizmus koordinálásáért felelös személy) véleménye szerint az 1. táblázatban meghatározott turisztikai és gazdaságfejlettségi mutatók 
Marton István : A Balaton régió fejlettségét meghatározó változóknak és a települési szakemberek véleményének összehasonlító elemzése. Tér és Társadalom 19. évf. 2005/3-4. 159-170. p.

TÉT XIX. évf. 2005 - 3-4

Gyors ténykép

161

milyen mértékben játszanak szerepet településük életében. A turisztikai és gazdaságfejlettségi mutatók 1-5-ig terjedő skálán kerültek értékelésre a kérdöívet kitöltökkel. Az 5-ös érték jelentette, hogy az adott változó kiemelt fontosságú a Balaton régió településeinek életében, értelemszerüen az 1-es értéket azok a változók kapták, amelyek a legkisebb szereppel bímak. A településenként és változónként kapott súlyértékeket aszerint átlagoltuk, hogy a súlyszámot a Balaton régió melyik övezetében (partközeli vagy további) elhelyezkedö település szakemberei adták. Eredményként mind a 36 változóhoz hozzá tudtuk rendelni egy, a települési szakemberek által szolgáltatott súlyértéket.

A statisztikai adatok és a kérdőíves kutatásból származó súlyszámok segítségével Komplex Fejlettségi Mutatót (KFM) számoltunk. A KFM-értéket mind gazdaságfejlettségi, mind turisztikai tekintetben kiszámoltuk a Balaton régió összes (164) településére vonatkozóan, majd ezt követően elemeztük a településcsoportok egymáshoz viszonyított fejlettségét e mutató értékei alapján. A rendelkezésre álló adatok (a változók) nem azonos nagyságrendủek és mértékegységủek, ezért elöször egy skála-összehangoló transzformációt végeztünk el, hogy az adatokat együttesen lehessen kezelni (Molnár 2001). Azon változók esetében, ahol a változók magas értékei negatív irányban befolyásolták az adott település fejlettségét (elvándorlás, halálozási ráta, 60 éven felüliek aránya), a változó reciprokával szoroztuk be az egyenletet.

A Komplex Fejlettségi Mutató kiszámításához az alábbi képletet használtuk:

$K F M=\frac{\sum \frac{\left(X_{i}-X_{\text {min }}\right)}{T_{x}} \cdot S_{i}}{S_{\text {össz }}}$

Ahol:

KFM $=$ az adott település Komplex Fejlettségi Mutatója,

$X_{\min }=$ adott $x$ változó minimális értéke a települések között,

$\mathrm{X}_{\mathrm{i}}=$ adott $\mathrm{x}$ változó az adott településen,

$\mathrm{T}_{\mathrm{x}}=$ adott mutató terjedelme (a legnagyobb és a legkisebb értékkel rendelkező település közötti különbség).

$\mathrm{S}_{\mathrm{i}} \quad=$ adott $\mathrm{x}$ változó súlyértéke

$\mathrm{S}_{\text {össz }} \quad=$ a súlyok összértéke az adott övezetben

Ezen eljárás során minden változó azonos (0-1-ig terjedő) mérőskálán jelenik meg, így elvégezhető az összehasonlító elemzés. A gazdaságfejlettséghez kapcsolódó 17 és a turizmushoz kapcsolódó 19 érték számtani átlagát véve kaptuk meg a településenkénti két Komplex Fejlettségi Mutatót, egyet gazdaságfejlettségi és egyet turisztikai vonatkozásban. A továbbiakban ennek a komplex mutatónak a segítségével elemezzük a Balaton régió településeit. 
Marton István : A Balaton régió fejlettségét meghatározó változóknak és a települési szakemberek véleményének összehasonlító elemzése. Tér és Társadalom 19. évf. 2005/3-4. 159-170. p.

\section{Eredmények}

\section{A térségi szakemberek véleményének elemzése}

A partközeli településeken, mind a gazdaságfejlettségi, mind pedig a turisztikai változókhoz rendelt súlyértékek (a változók fontossága) meghaladják a további települések súlyértékeit. Míg a partközeli településeken a gazdaságfejlettségi és a turizmushoz kapcsolódó változók közel azonos arányban kaptak szerepet, addig a további településeken a turisztikai változók jóval kevésbé hangsúlyosak, mint a fejlettségi szintet meghatározók (1. táblázat). A legfontosabb vizsgált tényezök közül a partközeli településeken a legmagasabb értékkel a csatornahálózat hossza $(4,47)$ és a közüzemi vízvezetékbe bekapcsolt lakások szerepelnek $(4,33)$. A legkevésbé hangsúlyos változók a munkanélküliséghez kapcsolódók; a munkanélküliek aránya $(3,33)$, tartós munkanélküliek aránya $(3,07)$. A partközeli települések turisztikai változói között a kereskedelmi szálláshelyeken eltöltött vendégéjszakák száma $(4,13)$ és a tartózkodási idő $(4,13)$ a legfontosabb. A legalacsonyabb súlyértékek a falusi turizmushoz köthetőek, mind a tartózkodási idő $(2,13)$, mind pedig a szállásférőhelyek száma $(1,93)$ alacsony értéket kapott.

A további települések esetében, a gazdaságfejlettségi mutatók közül, a közüzemi vízvezetékbe bekapcsolt lakások $(4,33)$ arányán túl, fontosnak találták a 60 évnél idősebb népesség arányát $(3,67)$, és a települések átlagos lélekszámát $(3,67)$ (elöregedés, elvándorlás!). A turisztikai mutatók jellemzöen alacsonyabb értékkel szerepeltek a további településeken. Alig meghaladva a 2-es értéket az összes kereskedelmi szállásférőhely $(2,05)$ és a külföldi vendégéjszakák $(2,19)$ szerepeltek az élen. Legalacsonyabb értékeket a szállodai vendégéjszakák $(1,62)$ és szállásférőhelyek $(1,81)$ kaptak.

\section{TÁBLÁZAT}

A gazdasagfejlettségi és turisztikai elemzéshez felhasznált változók, a hozzájuk tartozó súlyértékek és Komplex Fejlettségi Mutatók

(Variables Used for Economy Development and Turistical Analysis, Their Weighted Values and the Komplex Development Indexes)

\begin{tabular}{lccccc}
\hline \multirow{2}{*}{ Gazdaságfejlettségi változók } & \multicolumn{3}{c}{ Súly } & \multicolumn{2}{c}{ KFM } \\
\cline { 2 - 5 } & partközeli & további & partközeli & további \\
\hline Müködó gazdasági szervezetek száma & 3,33 & 2,67 & 0,548 & 0,284 \\
Szja.- alapot képzö jövedelem & 3,93 & 3,1 & 0,526 & 0,326 \\
Közüzemi vízvezeték-hálózatba bekapcsolt & 4,33 & 4,33 & 0,721 & 0,704 \\
lakások & 4,47 & 3,19 & 0,278 & 0,090 \\
Csatornahálózat hossza & 3,87 & 3,52 & 0,837 & 0,401 \\
Vezetékes gázellátásba bekapcsolt háztartások & 4,33 & 2,24 & 0,169 & 0,008 \\
száma & 3,6 & 3,1 & 0,107 & 0,034 \\
Vendégéjszakák száma & 3,93 & 3,38 & 0,420 & 0,245 \\
Kiskereskedelmi boltok száma & 3,73 & 2,95 & 0,657 & 0,361 \\
Távbeszélök száma & & &
\end{tabular}


Marton István : A Balaton régió fejlettségét meghatározó változóknak és a települési szakemberek véleményének összehasonlító elemzése. Tér és Társadalom 19. évf. 2005/3-4. 159-170. p.

TÉT XIX. évf. 2005 - 3-4

Gyors ténykép

163

\section{TÁBLÁZAT folytatása}

\begin{tabular}{|c|c|c|c|c|}
\hline \multirow[t]{2}{*}{ Gazdaságfejlettségi változók } & \multicolumn{2}{|c|}{ Súly } & \multicolumn{2}{|c|}{$K F M$} \\
\hline & partközeli & további & partközeli & további \\
\hline Személygépkocsik száma & 3,53 & 3,33 & 0,296 & 0,168 \\
\hline Betelepülők száma & 313 & 3 & 0,150 & 0,105 \\
\hline Elvándorlók száma & 3,13 & 3 & 0,076 & 0,084 \\
\hline 60 évnél idősebb népesség & 3,67 & 3,67 & 0,406 & 0,208 \\
\hline A települések átlagos lélekszáma & 3,67 & 3,67 & 0,428 & 0,206 \\
\hline Halálozási ráta & 3 & 3,19 & 0,866 & 0,772 \\
\hline Munkanélküliek száma & 3,33 & 2,95 & 0,131 & 0,312 \\
\hline Tartós (180 napon túli) munkanélküliek száma & 3,07 & 2,81 & 0,025 & 0,132 \\
\hline Turisztikai változók & partközeli & további & partközeli & további \\
\hline $\begin{array}{l}\text { Összes kereskedelmi szálláshely szállásférőhe- } \\
\text { lyeinek száma }\end{array}$ & 4,13 & 2,05 & 0,150 & 0,009 \\
\hline $\begin{array}{l}\text { Vendégéjszakák száma a kereskedelmi szálláshe- } \\
\text { lyeken }\end{array}$ & 4,33 & 1,9 & 0,210 & 0,011 \\
\hline $\begin{array}{l}\text { Átlagos tartózkodási idő a kereskedelmi szállás- } \\
\text { helyeken }\end{array}$ & 3,8 & 1,95 & 0,202 & 0,121 \\
\hline $\begin{array}{l}\text { Külföldiek által eltöltött vendégéjszakák száma a } \\
\text { kereskedelmi szálláshelyeken }\end{array}$ & 4 & 1,95 & 0,285 & 0,023 \\
\hline Szállodák szállásférőhelyeinek száma & 3,53 & 1,81 & 0,157 & 0,011 \\
\hline Vendégéjszakák száma a szállodákban & 3,53 & 1,62 & 0,074 & 0,006 \\
\hline Külföldi vendégéjszakák száma a szállodákban & 3,07 & 1,67 & 0,056 & 0,005 \\
\hline Átlagos tartózkodási idő szállodákban & 3,53 & 1,67 & 0,190 & 0,019 \\
\hline $\begin{array}{l}\text { Vendégéjszakák száma egyéb szálláshelyeken } \\
\text { (panziók, tur.száll., kemp., üdülőh.) }\end{array}$ & 3,87 & 2,05 & 0,106 & 0,003 \\
\hline $\begin{array}{l}\text { Külföldi vendégéjszakák száma egyéb szállás- } \\
\text { helyeken }\end{array}$ & 3,93 & 2,19 & 0,110 & 0,004 \\
\hline $\begin{array}{l}\text { Átlagos tartózkodási idő a kereskedelmi szállás- } \\
\text { helyeken }\end{array}$ & 4,13 & 2,05 & 0,159 & 0,027 \\
\hline Magán szállásadás férỏhelyeinek száma & 3,87 & 2,19 & 0,128 & 0,010 \\
\hline Vendégéjszakák a magánszállásadásban & 4 & 2,1 & 0,209 & 0,029 \\
\hline Külföldi vendégéjszakák a magánszállásadásban & 3,67 & 2,1 & 0,223 & 0,027 \\
\hline Átlagos tartózkodási idő a magánszálláshelyeken & 3,87 & 2,05 & 0,097 & 0,114 \\
\hline Falusi szállásadás férőhelyeinek száma & 1,93 & 2 & 0,068 & 0,059 \\
\hline Vendégéjszakák a falusi szállásadásban & 2,13 & 1,95 & 0,017 & 0,028 \\
\hline Külföldi vendégéjszakák a falusi szállásadásban & 1,87 & 1,9 & 0,014 & 0,015 \\
\hline Átlagos tartózkodási idő a falusi szállásadásban & 2,13 & 2 & 0,037 & 0,113 \\
\hline
\end{tabular}

Forrás: Saját számítás. 
Marton István : A Balaton régió fejlettségét meghatározó változóknak és a települési szakemberek véleményének összehasonlító elemzése. Tér és Társadalom 19. évf. 2005/3-4. 159-170. p.

A helyi szereplök véleményének és a statisztikailag mérhetö eredmények összehasonlító vizsgálata

A következőkben együtt vizsgáljuk a területi szereplők által szolgáltatott információkból (a változókhoz rendelt súlyérték), és a Balaton régió településeinek statisztikai elemzéséből (Komplex Fejlettségi Mutató) származó adatokat. Arra keressük a választ, hogy a helyi szereplők fejlesztési prioritási sorrendje és a meglévő statisztikailag mérhetö adottságok milyen összefüggésben állnak egymással. Az oszlopok jelzik az adott változó települési szakemberek által szolgáltatott súlyértékeinek átlagát, és kék színnel jelöltük az adott változóhoz tartozó települési komplex mutató átlagos értékeit.

\section{Partközeli települések gazdaságfejlettségi vizsgálata}

A gazdaságfejlettséget meghatározó változók súlyátlagának értéke 3,65, a települések gazdaságfejlettségét meghatározó komplex mutató értékének átlaga 0,39 volt a Balaton régió partközeli településein. Az alábbiakban látható, hogy a partközeli településeken az átlagosnál magasabb súlyszámmal rendelkező (ebböl következően a település gazdaságfejlettségét az átlagosnál nagyobb mértékben befolyásoló) változókhoz milyen statisztikailag mérhető teljesítmény tartozik.

\section{1. ÁBRA}

A 17 gazdaságfejlettségi változóhoz kapcsolódó súlyérték, és a változók átlagos KFM értéke a Balaton régió partközeli településein

(Weighted Values of the 17 Ecenomy Development Variables and Their Average Komplex Development Indexes on the Inshore Settlements of Balaton Region)

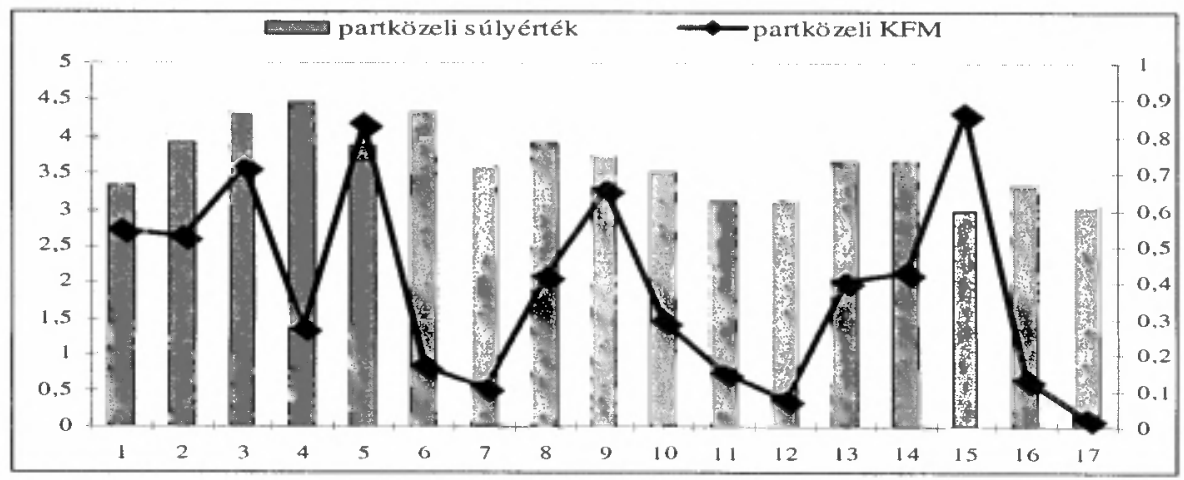

Forrás: Sajất számítás.

A partközeli településeken, a települési szakemberek véleménye szerint, az átlagosnál fontosabb a 17 kiválasztott mutató közül:

- 2.1 állandó lakosra jutó szja.- alapot képző jövedelem (3,93),

- 3. Közüzemi vízvezeték-hálózatba bekapcsolt lakások aránya 1000 lakásra $(4,33)$, 
Marton István : A Balaton régió fejlettségét meghatározó változóknak és a települési szakemberek véleményének összehasonlító elemzése. Tér és Társadalom 19. évf. 2005/3-4. 159-170. p.

TÉT XIX. évf. 2005 - 3-4

Gyors ténykép

165

- $4.1 \mathrm{~km}$ vízvezetékre jutó csatornahálózat hossza $(4,47)$,

- 5. Vezetékes gázellátásba bekapcsolt háztartások száma a lakásállomány százalékában $(3,87)$,

- 6. 1000 lakosra jutó vendégéjszakák száma (4,33),

- 8. 1000 lakosra jutó távbeszélök száma $(3,93)$,

- 9. Utóbbi 10 évben épített 3-X szobás lakások aránya (3,73).

Ha megvizsgáljuk az átlagosnál nagyobb fontossággal bíró változókhoz tartozó KFM-értékeket, arra a következtetésre jutunk, hogy a 4. $(0,27)$ és a $6 .(0,17)$ esetben a statisztikailag mérhető eredmények átlag alattiak, pedig az adott változó a területi szakemberek véleménye szerint az átlagosnál nagyobb szerepet játszik a település életében. A szakemberek véleményének és a statisztikai adatoknak az összevetéséböl az derül ki, hogy a Balaton régió partközeli településein a csatornahálózat hosszának és a vendégéjszakák számának a növelése a két legfontosabb fejlesztési prioritás.

\section{Partközeli települések turisztikai vizsgálata}

Jelen esetben is azt vizsgáltuk, hogy az egyes - turizmushoz kapcsolódó - változóknak mekkora fontosságot tulajdonítanak a települési szakemberek, és milyen a változókhoz kapcsolódó mérhető statisztikai eredmény. A 2. ábrán is oszlopok jelzik az adott változó települési szakemberek által szolgáltatott súlyértékeinek (fontosságának) átlagát, és kék színnel jelöltük az adott változóhoz tartozó települési komplex mutató átlagos értékeit. A partközeli települések turisztikai változóinak súlyátlaga 3,43 volt, a települések átlagos turisztikai Komplex Fejlettségi Mutatója pedig 0,13 .

\section{2. ÁBRA}

A 19 turisztikai változóhoz kapcsolódó súlyérték és a változók átlagos KFM-értéke a Balaton régió partközeli településein

(Weighted Values of the 17 Turistical Variables and Their Average Complex

Development Indexes on the Inshore Settlements of Balaton Region)

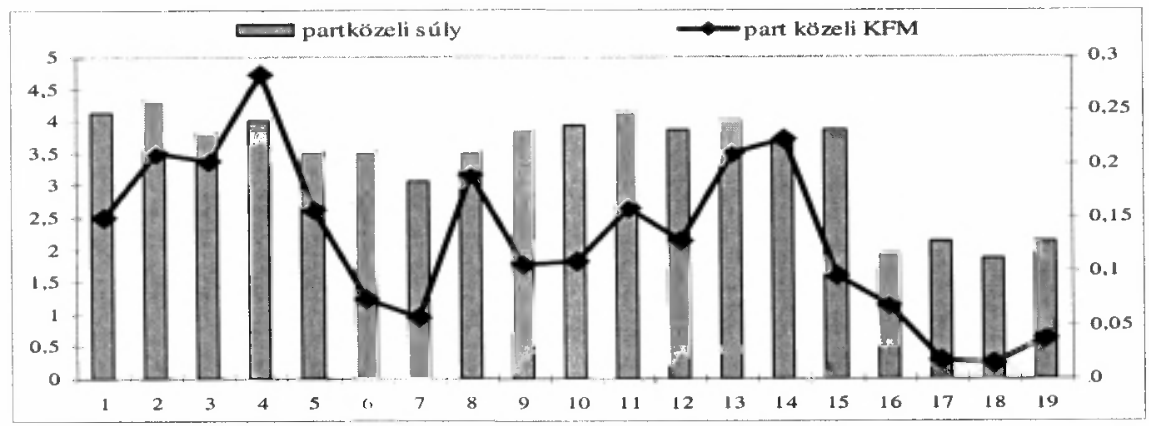

Forrás: Saját számítás. 
Marton István : A Balaton régió fejlettségét meghatározó változóknak és a települési szakemberek

véleményének összehasonlító elemzése. Tér és Társadalom 19. évf. 2005/3-4. 159-170. p.

166 Gyors ténykép

TÉT XIX. évf. 2005 -3-4

A partközeli településeken az alábbi változókat tartották az átlagosnál fontosabbnak a települési szakemberek:

- I. Összes kereskedelmi szálláshely szállásférőhelyeinek száma $(4,13)$,

- 2. Vendégéjszakák száma a kereskedel mi szálláshelyeken $(4,33)$,

- 3. Átlagos tartózkodási idő a kereskedelmi szállăshelyeken (3,8),

- 4. Külföldiek által eltöltött vendégéjszakák száma a kereskedelmi szálláshelyeken (4),

- 5. Szállodák szállásférőhelyeinek száma $(3,53)$,

- 6. Vendégéjszakák száma a szállodákban $(3,53)$,

- 8. Átlagos tartózkodási idő a szállodákban (3,53),

- 9. Vendégéjszakák száma egyéb szálláshelyeken (panziók, turistaszállások, kempingek, üdülőházak) $(3,87)$,

- 10. Külföldi vendégéjszakák száma egyéb szálláshelyeken $(3,93)$,

- 11. Átlagos tartózkodási idő a kereskedelmi szálláshelyeken $(4,13)$,

- 12. Magánszállásadás férőhelyeinek száma $(3,87)$,

- 13. Vendégéjszakák a magánszállásadásban (4),

- 14. Külföldi vendégéjszakák a magánszállásadásban $(3,67)$,

- 15. Átlagos tartózkodási idő a magánszálláshelyeken $(3,87)$.

A nagyszámú, az átlagot meghaladó változó oka, hogy a partközeli településeken nagyon kismértékủ a falusi turizmus (jogszabályi és adottsági korlátokból következően), és ez jelentősen csökkenti az átlagot, így a többi változó meghaladja azt.

Ha a turisztikai változók esetében is megvizsgáljuk az átlagosnál nagyobb fontossággal bíró változókhoz tartozó KFM-értékeket, arra a következtetésre jutunk, hogy a 6. $(0,073), 9 .(0,1), 10 .(0,11), 12 .(0,128)$, és $15 \cdot(0,096)$ esetben a statisztikailag mérhetô eredmények átlag alattiak, azon változók esetében, amelyeknek a területi szakemberek az átlagosnál nagyobb szerepet tulajdonítanak a település életében. A szakemberek véleményének és a statisztikai adatoknak az összevetésébỏl az derül ki, hogy a fö feladat a szállodai vendégéjszakák számának növelése. Továbbá még mindig jelentős szerepet tulajdonítanak az egyre inkább teret vesztỏ magánszállásadásnak (magas súlyértékek, alacsony valós teljesítmény). 
Marton István : A Balaton régió fejlettségét meghatározó változóknak és a települési szakemberek véleményének összehasonlító elemzése. Tér és Társadalom 19. évf. 2005/3-4. 159-170. p.

TÉT XIX. évf. 2005 @ 3-4

Gyors ténykép

167

További települések gazdaságfejlettségi vizsgálata

\section{ABRA}

A 17 gazdaságfejlettségi változóhoz kapcsolódó súlyérték és a változók átlagos KFM-értéke a Balaton régió további településein

(Weighted Values of the 17 Ecenomy Development Variables and Their Average

Komplex Development Indexes on the Other Settlements of Balaton Region)

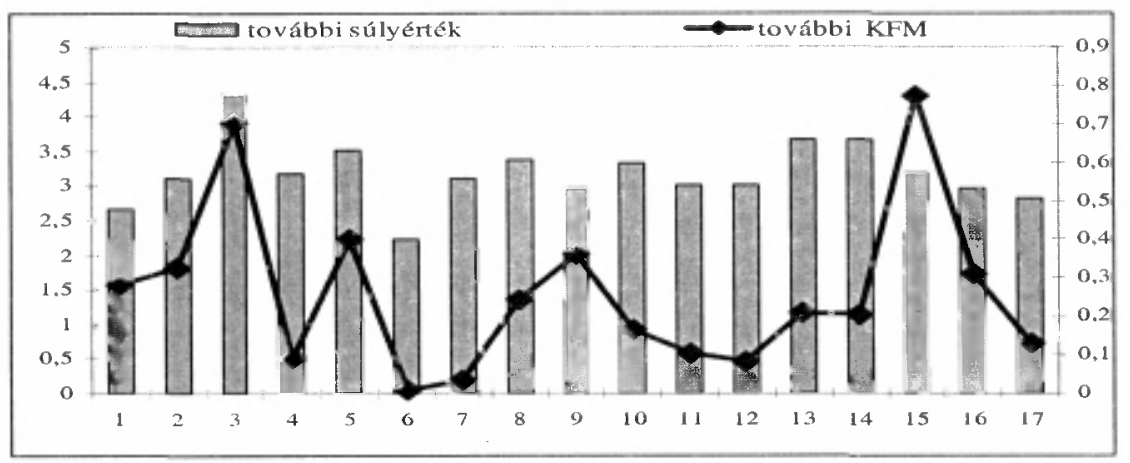

Forrás: Saját számítás.

A 3. ábrán hasonlóan az elóbbihez a további települések helyi szereplöinek fontossági sorrendjét vetjük össze az adottságok statisztikailag mérhetỏ eredményeivel. A további telepuilések gazdaságfejlettséget meghatározó változóinak súlyátlaga 3,18 volt, a települések gazdaságfejlettségét meghatározó komplex mutató értékének átlaga pedig 0,26. A partkơzeli településeken a telepủlési szakemberek véleménye szerint az átlagosnál fontosabb a 17 kiválasztott mutató közül:

- 3. Közüzemi vízvezeték-hálózatba bekapcsolt lakások aránya 1000 lakásra $(4,33)$,

- $\quad 4.1 \mathrm{~km}$ vízvezetékre jutó csatornahálózat hossza $(3,19)$,

- 5. Vezetékes gázellátásba bekapcsolt háztartások száma a lakásállomány százalékában $(3,52)$,

- 8. 1000 lakosra jutó távbeszélök száma $(3,38)$,

- 10.1000 lakosra jutó személygépkocsik száma (3,33),

- $\quad 13.1000$ före jutó 60 évnél idỏsebb népesség arányának a reciproka $(3,67)$,

- 14. A telepủlések átlagos lélekszáma $(3,67)$.

Az átlagosnál nagyobb fontossággal bíró változókhoz tartozó KFM értékeket vizsgálva arra a kỏvetkeztetésre jutottunk, hogy a 4. $(0,09), 8 .(0,24), 10 \cdot(0,16)$, 13. $(0,2), 14$. $(0,2)$ esetben a statisztikailag mérhetỏ eredmények átlag alattiak, pedig az adott változó a területi szakemberek véleménye szerint az átlagosnál nagyobb szerepet játszik a telepuilés életében. Amennyiben tehát a szakemberek véleményét statisztikai adatokkal támasztjuk alá, az derül ki, hogy a Balaton régió további telepuilésein a csatornahálózat hosszának, a telefonvonalak és a gépkocsik 
Marton István : A Balaton régió fejlettségét meghatározó változóknak és a települési szakemberek véleményének összehasonlító elemzése. Tér és Társadalom 19. évf. 2005/3-4. 159-170. p.

számának (az elérhetőségnek, mobilitásnak) a növelése fontos (a telefonvonalak számának vizsgálati eredményeit árnyalhatja a mobilkommunikáció térnyerése), továbbá valós, statisztikailag igazolható probléma a települések elöregedése és a települések népességének a csökkenése.

További települések turisztikai vizsgálata

\section{4. ÁBRA}

A 19 turisztikai változóhoz kapcsolódó súlyérték és a változók átlagos KFM-értéke a Balaton régió további településein

(Weighted Values of the 17 Turistical Variables and Their Average Complex Development Indexes on the Other Settlements of Balaton Region)

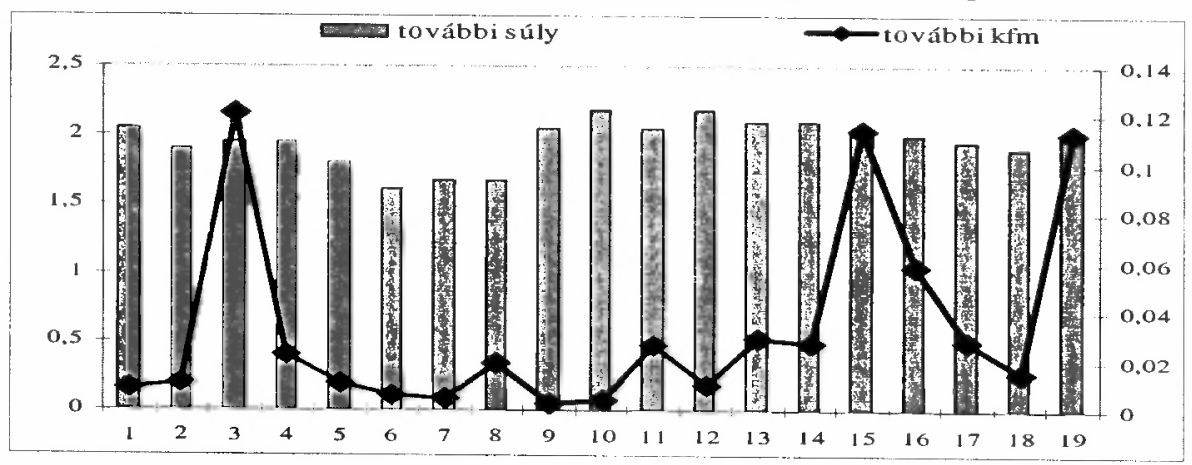

Forrás: Saját számítás.

A Balaton régió további településein jóval kisebb szerepet tulajdonítanak a turizmusnak, mint a partközeli településeken, jól látszik ez az alacsony súlyértékekből. A statisztikailag mérhetó eredmények (KFM, kék vonal) is azt mutatják, hogy a településeken alacsony a turisztikai forgalom. A további településeken átlagosan 1,95-re értékelték a helyi szakemberek a turizmus fontosságát és a KFM statisztikai mutató értéke is mérsékelt, mindössze 0,033. A további telepủléseken az alábbi mutatókat tartották fontosnak a helyi szakemberek:

- 1. Összes kereskedelmi szálláshely szállásférőhelyeinek száma (2,05),

- 9. Vendégéjszakák száma egyéb szálláshelyeken (panziók, turistaszállások, kempingek, üdülóházak) (2,05),

- 10. Külföldi vendégéjszakák száma egyéb szálláshelyeken $(2,19)$,

- 11. Átlagos tartózkodási idó a kereskedelmi szálláshelyeken $(2,05)$,

- 12. Magánszállásadás féróhelyeinek száma (2,19),

- 13. Vendégéjszakák a magánszállásadásban (2,1),

- 14. Külföldi vendégéjszakák a magánszállásadásban (2,1),

- 15. Átlagos tartózkodási idő a magánszálláshelyeken $(2,05)$,

- 16. Falusi szállásadás féröhelyeinek száma (2),

- 17. Átlagos tartózkodási idő a falusi szállásadásban (2). 
Bár jelentős számú változó haladja meg az átlagos értékeket, azokat vizsgálva megállapítható, hogy nincs olyan, ami kiugróan magas lenne. Mindezekböl az következik, hogy a további településeken nincs olyan típusú turizmus, amely a települési szakemberek szerint „,húzóágazatként” tudna részt venni a település életében. $\mathrm{Az}$ átlagos értékeket meghaladó változókat vizsgálva arra a megállapításra juthatunk, hogy az 1. $(0,009), 9 .(0,002), 10 .(0,004), 1 \cdot 1 \cdot(0,026), 12 .(0,01), 13 .(0,029)$, 14. $(0,027)$ változók, bár a település életében betöltött fontosságuk a települési szakemberek szerint átlag feletti, a statisztikailag mérhetö eredményeik az átlag alatt maradnak. Ebböl következöen a további települések turizmusának fejlesztésekor célszerü lehet szem elött tartani a szálláshelykínálat növelését és az egyéb szálláshelyeken (panziók, turistaszállások, kempingek, üdülőházak) eltöltött vendégéjszakák számának növelését. Ez a látszólag triviális megállapítás is azt igazolja, hogy a további települések turizmusa olyannyira fejletlen, hogy nincs egyetlen olyan „turisztikai termék” sem, amelyet különösen fontosnak találtak volna a települési szakemberek. Ehelyett a turizmus általános feltételeinek javítását és a vendégéjszakák számának a növelését tartják lényegesnek. A 12, 13, 14 számú (magánszállásadáshoz kapcsolódó) változók magas súlyértékei (ezen változóknak a települési szakemberek az átlagosnál nagyobb szerepet tulajdonítanak) és a hozzájuk kapcsolódó átlag alatti teljesítmények azt mutatják, hogy még mindig megvan a bizalom ezen jobb napokat látott szállásadási forma iránt. Ugyanakkor a turisták igényszintjének emelkedése és a hiányos infrastruktúra következtében csökken a magánszállásadás szerepe az igényeket jobban kielégítö szálláshelyekkel szemben. Rengeteg az eladó, elsösorban kiadás céljára épített ingatlan, amelyek hiteleit a tulajdonosok a vendégforgalom elmaradása miatt fizetni képtelenek.

\section{Összefoglalás}

A rendszerváltás óta nemcsak a régiók közötti különbségek erösödtek fel, hanem a régiót alkotó települések között is jelentős fejlettségbeli eltérések tapasztalhatók. A regionális tudományok egyik feladata a különbségek okainak kutatása és a fejlettségbeli eltérések mérséklése. A Balaton régió települései között egyfajta intraregionális fejlettségbeli eltérés jelentkezik, aminek egyik legföbb oka a térség vezető iparágának, a turizmusnak a területi koncentrációja. Ennek következtében, a partközeli települések térbeli elhelyezkedésükből adódóan jelentős fejlettségbeli elönyre tettek szert a régió további településeihez képest.

Az európai uniós csatlakozásunkkal az inter- és intraregionális különbségek csökkentésére felhasználható központi fejlesztési források a többszörösére növekedtek, ugyanakkor a pályázati folyamatnak is EU-kompatibilissá kellett válnia. A fejlesztési források elosztásánál az egyik legfontosabb szempont az adott területi egység fejlettségének meghatározása. A szerzỏ véleménye szerint a statisztikai vizsgálatok bármilyen mutatórendszerrel is dolgoznak, nem képesek figyelembe venni a területi sajátosságokat, ebből kifolyólag elfedhetnek fontos eredményeket. Árnyalhatjuk a vizsgálatok eredményeit az eltérő fejlettségü településcsoportok meghatározásánál, 
ha együtt vizsgáljuk a területi szereplők által szolgáltatott információkat és a Balaton régió településeinek statisztikai elemzéséböl származó adatokat.

A sokak által irigyelt „gazdag” Balaton régió számos súlyos problémával küzd. Települései között hatalmas fejlettségbeli eltérések vannak, a régión belüli (interregionális) különbségeit a regionális szintü elemzésekben elfedik a partközeli települések országost meghaladó értékei. A partközeli települések fejlettsége sokszorosa a gyakran az országos színvonal alatt teljesítỏ további településekének. A vizsgálatok alapján elmondhatjuk, hogy a Balaton régióban a területi egyenlötlenségek nem kizárólag a településmérettel vannak összefüggésben. A régió településeinek fejlettségét sokkal inkább a Balaton-parthoz való közelség határozza meg. A Balaton régió településszerkezetének analízise azt mutatta, hogy egy fö töréspont mentén lehet vizsgálni a régiót alkotó településeket. Ez a töréspont a tótól, azaz a régió legfontosabb turisztikai vonzerejét jelentő Balaton-parttól való távolság. A Balaton régió különféle, gazdasági és turisztikai adatait elemezve azt tapasztalhatjuk, hogy a régió telepưlésein a fejlettséget és jólétet jelző mutatók annál magasabbak, minél közelebb vagyunk a parthoz. Mindezekböl adódóan úgy is lehet fogalmazni, hogy a Balaton régió centruma nem néhány nagyobb lélekszámú város, hanem a centrum valójában maga a Balaton-part, a parti területek gyorsan összenövő, agglomerálódó településegyüttese. Mindazonáltal a vizsgált adatok azt mutatják, hogy a régió népessége, gazdasági és turisztikai potenciálja, így erőforrásainak nagy hányada 12-15 (jellemzően partközeli) településen koncentrálódik.

Az egyre rövidebb szezon és a szinte csak a vízre korlátozott kínálat még a partközeli településeken élők közül sem kínált mindenki számára megélhetési alternatívát. Bizonyos mértékben a helyi lakosok közül sokan profitálnak a turizmusból, de eredményeim szerint felül kell bírálni azt a hamis látszatot, hogy a régió népességének egésze meghatározóan a balatoni turizmusból él. Mindemellett a Balaton jelentös nemzetközi érdeklödésre is számot tartó egyedülálló természeti értéket képvisel. A turisztikai ágazat világméretủ fejlődését tekintve az ország egyik legsikeresebb régiójává válhat. Turisztikai kiaknázása az egész magyar idegenforgalmi ágazat kulcskérdése.

\section{Irodalom}

Nemes Nagy J. (kutatásvezetö) (2003) A Balaton régió gazdasági fejlettsége a GDP térségi becslése tuikrében, (Kutatási jelentés). R-DATA Bt., ELTE Regionális Földrajzi Tanszék, MTA-ELTE Regionális Tudományi Kutatócsoport, Budapest.

Molnár T. (2001) Társadalmi-gazdasági struktúrák regionális jellemzöi a Nyugat-Dunántúlon. Keszthely. PhD Doktori értekezés.

Vanicsek M. (kutatásvezetō) (2000) A "Balaton régió" jövedelemtermelését, jövedelem elvonását, befektetési, beruházási jellemzöit feltáró jövedelemmérleg elkészítése, a jövedelmek korszerüsített újraelosztására vonatkozó javaslat és program. Budapest. 